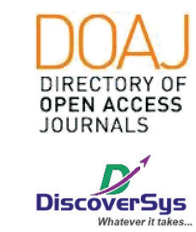

Published by DiscoverSys

\section{Tingkat pengetahuan dokter umum mengenai bukti medis kekerasan seksual di RSUD se-Provinsi BALI tahun 2017}

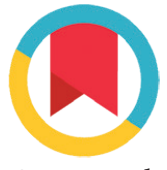

CrossMark

\author{
I Gusti Ayu Agung Dwijayanti, ${ }^{1 *}$ Dudut Rustyadi, ${ }^{2}$ Kunthi Yulianti ${ }^{2}$
}

\section{ABSTRACT}

Background: Sexual violence is a frequent criminal offense. Targets that become victims of the crimes can be women even today many occur in children. Medical evidence is the key to the proof of a case of sexual violence that is usually made by a forensic specialist. A general practitioner is expected to be able to examine the medical evidence of sexual violence considering the number of forensic specialists who are not comparable with the geographical area of Indonesia.

Aim: The study aims to know the level of knowledge and relation between the variable of age, practice experience, and level of education related to the knowledge level of general practitioners about medical evidence of sexual violence.

Method: This study is descriptive cross-sectional research located at Emergency Department all over General Hospital in Bali Province.
The subject is general physician $\leq 60$ years old. Data obtained use questionnaire containing a set of questions.

Result: The results showed the general practitioner knowledge level about medical evidence of sexual violence was good. Of the 110 samples, $87.3 \%$ had a good level of knowledge, $11.8 \%$ was sufficient, and $0.9 \%$ had less knowledge level. One variable influenced the general physician's knowledge level was practical experience $(p=0.039)$. Moreover, the age $(p=0.908)$ did not have a significant relationship to the general practitioner knowledge level about medical evidence of sexual violence.

Conclusion: It is essential that practical experience for a doctor's knowledge level about medical evidence of sexual violence is critically important.

Keywords: Knowledge level, medical evidence, sexual violence, general practitioner

Cite This Article: Dwijayanti, I.G.A.A., Rustyadi, D., Yulianti, K. 2019. Tingkat pengetahuan dokter umum mengenai bukti medis kekerasan seksual di RSUD se-Provinsi BALI tahun 2017. Intisari Sains Medis 10(1): 77-81. D0I: 10.1556/ism.v10i1.245

\title{
ABSTRAK
}

Kasus kekerasan seksual merupakan tindakan kriminal yang sering terjadi. Sasaran yang menjadi korban kejahatan ini bisa wanita bahkan saat ini banyak terjadi pada anak-anak dibawah umur. Bukti medis adalah kunci pembuktian kasus kekerasan seksual yang biasanya dibuat oleh dokter spesialis forensik. Seorang dokter umum diharapkan mampu melakukan pemeriksaan bukti medis kekerasan seksual mengingat jumlah dokter spesialis forensik yang tidak sebanding dengan luas geografis wilayah Indonesia.

${ }^{1}$ Program Studi Pendidikan Dokter, Fakultas Kedokteran Universitas Udayana

${ }^{2}$ SMF Kedokteran Forensik, Rumah Sakit Umum Pusat SanglahUniversitas Udayana, BaliIndonesia

\section{*Corresponding:}

I Gusti Ayu Agung Dwijayanti, Program Studi Pendidikan Dokter, Fakultas Kedokteran Universitas Udayana

dwijayantigusti@gmail.com

Kata kunci: tingkat pengetahuan, bukti medis, dokter umum, kekerasan seksual

\section{PENDAHULUAN}

Kasus kekerasan seksual merupakan tindakan kriminal yang sering terjadi. Sasaran yang menjadi

Bali dengan sampel adalah dokter umum usia $\leq 60$ tahun. Data diambil dengan menggunakan kuesioner yang berisi sekumpulan pertanyaan.

Hasil: Hasil dari penelitian menunjukkan bahwa tingkat pengetahuan dokter umum mengenai bukti medis kekerasan seksual secara keseluruhan baik. Dari 110 sampel yang telah diteliti, 87,3\% memiliki tingkat pengetahuan baik, $11,8 \%$ memiliki tingkat pengetahuan cukup, dan 0,9\% memiliki tingkat pengetahuan kurang. Ada hal yang mempengaruhi tingkat pengetahuan dokter umum yaitu pengalaman praktik $(p=0,039)$ dokter umum sendiri. Sedangkan variabel usia $(p=0,908)$ tidak memiliki hubungan yang signifikan terhadap tingkat pengetahuan dokter umum mengenai bukti kekerasan seksual.

Simpulan: Hal ini menunjukkan bahwa pentingnya pengalaman praktik untuk tingkat pengetahuan dokter umum mengenai bukti medis kekerasan seksual .

Cite Pasal Ini: Dwijayanti, I.G.A.A., Rustyadi, D., Yulianti, K. 2019. Tingkat pengetahuan dokter umum mengenai bukti medis kekerasan seksual di RSUD se-Provinsi BALI tahun 2017. Intisari Sains Medis 10(1): 77-81. D0I: 10.1556/ism.v10i1.245

korban kejahatan ini bisa wanita bahkan saat ini banyak terjadi pada anak-anak dibawah umur. 
Kasus yang terjadi sangat beragam, mulai dari memperlihatkan alat kelamin sampai dengan penetrasi vaginal. Dari sejumlah kasus kekerasan seksual, sebagian besar pelakunya merupakan orang terdekat korban. Hal tersebut membuat rasa tidak aman bagi banyak orang.

Sebuah penelitian di Northwest Nigeria tahun 2015 menyebutkan terdapat 24 kasus kekerasan seksual (22 diantaranya diduga kasus pemerkosaan dan sisanya kasus yang lain) dari 973 kasus bagian konsultasi ginekologi di unit gawat darurat. Dari penelitian tersebut ditemukan prevalensi kekerasan seksual adalah 3\% atau 24 kasus dari 973 total kasus dan 2,3\% atau 22 kasus dari 973 total kasus merupakan dugaan pemerkosaan. ${ }^{1}$ Data dari CATAHU tentang kekerasan terhadap perempuan di Indonesia tahun 2016 menunjukkan peningkatan jumlah kasus. Sumber data CATAHU pada tahun 2015 adalah 95\% dari data kasus/perkara yang ditangani Pengadilan Agama dan 5\% dari lembaga-lembaga mitra pengada layanan. Jumlah kasus pada tahun-tahun sebelumnya seperti fenomena gunung es. Hal ini disebabkan banyak perempuan yang enggan dan tidak mau menceritakan pengalaman kekerasannya dan kurangnya lembaga mitra pengada pelayanan yang bisa menjadi tempat pengaduan kasus. $^{2}$

Pada data Komisi Perlindungan Anak tahun 2016, kasus kekerasan seksual terhadap anak dari tahun 2011 sampai tahun 2016 berjumlah 2001 kasus. Dengan jumlah kasus tertinggi pada tahun 2014 yaitu 656 kasus. Dari data Anak Berhadapan Hukum yaitu 7967 kasus, jumlah kasus kekerasan seksual anak memiliki jumlah yang tinggi yaitu 3520 kasus dengan rincian 2001 kasus anak sebagai korban dan 1519 kasus anak sebagai pelaku. ${ }^{3}$

Sementara untuk kasus kekerasan seksual di Bali, beberapa kasus terhimpun dari yang semula ditangani Bagian Pemberdayaan Perempuan Sekretariat Daerah Provinsi Bali sampai menjadi unit layanan khusus dari tahun 2009 sampai bulan Februari tahun 2012 terdapat 196 kasus. Dimana kasus kekerasan terhadap istri sebanyak 101 kasus, kekerasan dalam pacaran 16 kasus, kekerasan terhadap anak 24 kasus, kasus perkosaan 7 kasus, pencabulan atau pelecehan seksual 3 kasus, kekerasan dalam keluarga 44 kasus, dan penjualan perempuan 1 kasus. $^{4}$

Menurut Badan Pemberdayaan Perempuan dan Perlindungan Anak (BP3A) Provinsi Bali mencatat 141 kekerasan anak sepanjang tahun 2013, data tersebut direkap mulai bulan Januari hingga 10 Desember 2013. Jumlah kasus pelecehan seksual yang dialami anak mencapai 51 kasus. Tertinggi terjadi di Kabupaten Karangasem sebanyak 20 kasus, disusul Buleleng 10 kasus, Tabanan 7 kasus, Klungkung 5 kasus, Gianyar 4 kasus,
Denpasar 3 kasus, dan Jembrana 2 kasus. Pada tahun 2015 data Pusat Pelayanan Terpadu Pemberdayaan Perempuan dan anak (P2TP2A) Provinsi Bali menunjukkan terdapat 125 kasus yang terdiri dari 41 kasus kekerasan seksual pada anak dan 84 kasus kekerasan seksual pada perempuan.

Bukti medis adalah kunci pembuktian kasus kekerasan seksual dan yang biasanya membuat adalah dokter spesialis forensik. Sementara itu dokter spesialis forensik di Indonesia jumlahnya tidak sebanding dengan luas geografis wilayah, sehingga masih ada wilayah yang tidak terdapat dokter spesialis forensik. Hal tersebut mempengaruhi dokter umum dalam pekerjaannya jika harus membuat bukti medis kasus kekerasan seksual. Dokter umum secara tidak langsung telah menerapkan pengetahuannya mengenai bukti medis kasus kekerasan seksual sehingga dapat mempengaruhi tingkat pengetahuannya. Oleh karena itu dilakukan penelitian untuk mengetahui tingkat pengetahuan dokter umum mengenai bukti medis kekerasan seksual di seluruh Rumah Sakit Umum Daerah di Provinsi Bali mengingat keterbatasan dokter spesialis Forensik di Provinsi Bali.

\section{METODE}

Penelitian ini merupakan penelitian deskriptif observasional menggunakan desain cross-sectional. Penelitian ini dilaksanakan di di rumah sakit umum Kabupaten dan Kota di Provinsi Bali dan dilakukan pada November 2017 hingga Desember 2017. Kriteria sampel penelitian ini adalah seluruh dokter umum yang bekerja di Rumah Sakit Umum Daerah Kabupaten dan Kota di Provinsi Bali. Sampel yang dipilih dari populasi memenuhi kriteria inklusi yaitu dokter umum usia $\leq 60$ tahun, dokter umum yang berpraktik atau dokter fungsional di Rumah Sakit Umum Daerah di Provinsi Bali, dan bersedia mengisi kuesioner dengan lengkap. Serta tidak memenuhi kriteria eklusi yaitu menolak berpatisipasi, tidak menandatangani informed consent, dan dokter umum yang sedang mengambil PPDS.

Teknik penentuan sampel yang digunakan adalah cluster random sampling. Jumlah sampel minimum yang dihitung dengan rumus besar sampel untuk data nominal pada proporsi tunggal. Tidak ditemukan penelitian serupa sehingga $\mathrm{P}=$ 0,5 maka $\mathrm{Q}=1-\mathrm{P}=0,5$. Besar ketetapan relatif yang ditetapkan oleh peneliti yaitu $10 \%(\mathrm{~d}=0,1)$. Besarnya Z $\alpha=1,96$ untuk $\alpha=0,05$. Berdasarkan perhitungan, dibutuhkan minimal 96 dokter umum sebagai subjek penelitian. ${ }^{5}$ Variabel dalam penelitian ini diantaranya variabel terikat yaitu tingkat pengetahuan dokter umum mengenai bukti medis kekerasan seksual. Variabel bebas yaitu 
usia dan pengalaman praktik. Analisis univariat atau deskriptif digunakan untuk memberikan gambaran umum mengenai karakteristik tingkat pengetahuan dokter umum mengenai bukti medis kekerasan seksual. Sedangkan analisis bivariate digunakan untuk menguji hipotesis hubungan antara masing-masing variabel bebas terhadap variabel terikat.

\section{HASIL PENELITIAN}

Tingkat pengetahuan dokter umum mengenai bukti medis kekerasan seksual

Dari 110 sampel yang diteliti dalam penelitian ini, didapatkan hasil 96 orang $(87,3 \%)$ memiliki tingkat pengetahuan baik, 13 orang $(11,8 \%)$ memiliki tingkat pengetahuan cukup, dan 1 orang $(0,9 \%)$ memiliki tingkat pengetahuan kurang.

\section{Tingkat pengetahuan dokter umum} mengenai bukti medis kekerasan seksual di setiap Rumah Sakit Umum Daerah

Tingkat pengetahuan dokter umum mengenai bukti medis kekerasan seksual keseluruhan termasuk dalam kriteria baik. Namun ada beberapa dokter umum yang memiliki tingkat pengetahuan yang cukup dan satu dokter umum di Rumah Sakit Umum Daerah Buleleng memiliki tingkat pengetahuan kurang.
Rincian tingkat pengetahuan dokter umum mengenai bukti medis kekerasan seksual

Dari 35 pertanyaan di kuesioner, 4 pertanyaan membahas mengenai dasar hukum, 2 pertanyaan membahas mengenai definsi kekerasan seksual, 7 pertanyaan membahas mengenai jenis-jenis kekerasan seksual, dan 21 pertanyaan membahas mengenai bukti medis kekerasan seksual.

\section{Pengaruh usia terhadap tingkat pengetahuan dokter umum mengenai bukti medis kekerasan seksual}

Tingkat pengetahuan dokter umum mengenai bukti medis kekerasan seksual menurut usia dibagi menjadi 2 kategori yaitu $<40$ tahun dan $\geq 40$ tahun.

Berdasarkan tabel 4 dapat diketahui bahwa proporsi dokter umum yang memiliki tingkat pengetahuan baik pada usia $<40$ tahun yaitu $87,4 \%$, angka ini lebih tinggi dari pada dokter umum usia $\geq 40$ yaitu $86,7 \%$. Hal yang berkebalikan terjadi pada dokter umum yang tingkat pengetahuan cukup, dimana pada usia $\geq 40$ tahun lebih tinggi yaitu $13,3 \%$ dibandingkan usia $<40$ tahun yaitu $11,6 \%$. Sedangkan dokter umum yang memiliki tingkat pengetahuan kurang hanya terdapat pada usia $<40$ tahun yaitu 1 orang dengan rasio proporsi yang didapatkan yaitu 1,01. Tidak didapatkan pengaruh yang bermakna antara usia dan tingkat

Tabel 1 Distribusi tingkat pengetahuan responden mengenai bukti medis kekerasan seksual

\begin{tabular}{lcc}
\hline $\begin{array}{l}\text { Tingkat pengetahuan dokter umum } \\
\text { mengenai bukti medis kekerasan seksual }\end{array}$ & Jumlah & Persen (\%) \\
\hline Baik & 96 & $87,3 \%$ \\
Cukup & 13 & $11,8 \%$ \\
Kurang & 1 & $0,9 \%$ \\
\hline
\end{tabular}

Tabel 2 Tingkat pengetahuan dokter umum di setiap Rumah Sakit Umum Daerah

\begin{tabular}{|c|c|c|c|c|c|}
\hline \multirow[b]{2}{*}{ No } & \multirow[b]{2}{*}{ Nama Rumah Sakit } & \multicolumn{3}{|c|}{ Nilai } & \multirow[b]{2}{*}{ Total } \\
\hline & & Baik & Cukup & Kurang & \\
\hline 1 & RSUD Wangaya Denpasar & 11 & 3 & 0 & 14 \\
\hline 2 & RS Bhayangkara Denpasar Polda Bali & 5 & 0 & 0 & 5 \\
\hline 3 & RSUD Mangusada Badung & 9 & 1 & 0 & 10 \\
\hline 4 & RSUD Sanjiwani Gianyar & 11 & 1 & 0 & 12 \\
\hline 5 & RSUD Klungkung & 13 & 2 & 0 & 15 \\
\hline 6 & RSUD Bangli & 10 & 0 & 0 & 10 \\
\hline 7 & RSUD Karangasem & 8 & 0 & 0 & 8 \\
\hline 8 & RSUD Buleleng & 5 & 4 & 1 & 10 \\
\hline 9 & RSU Jembrana & 12 & 2 & 0 & 14 \\
\hline 10 & BRSU Tabanan & 12 & 0 & 0 & 12 \\
\hline Total & & 96 & 13 & 1 & 110 \\
\hline
\end{tabular}


Tabel 3 Rincian tingkat pengetahuan dokter umum mengenai bukti medis kekerasan seksual

\begin{tabular}{lcccc}
\hline & \multicolumn{3}{c}{ Nilai } & \multirow{2}{*}{ Total } \\
\cline { 2 - 3 } Materi yang diuji & Baik & Cukup & Kurang & $100 \%$ \\
\hline Dasar Hukum Kekerasan Seksual & $82,7 \%$ & $12,7 \%$ & $4,6 \%$ & $100 \%$ \\
Definisi Kekerasan Seksual & $93,6 \%$ & $0 \%$ & $6,4 \%$ & $100 \%$ \\
Jenis-jenis Kekerasan Seksual & $73,6 \%$ & $19,1 \%$ & $7,3 \%$ & $100 \%$ \\
Bukti Medis Kekerasan Seksual & $85,5 \%$ & $10.9 \%$ & $3,6 \%$ & \\
\hline
\end{tabular}

Tabel 4 Hasil uji kebebasan chi-square tingkat pengetahuan dokter umum dan usia

\begin{tabular}{|c|c|c|c|c|c|c|c|}
\hline & & \multicolumn{3}{|c|}{ Nilai } & \multirow[b]{2}{*}{ Total } & \multirow[b]{2}{*}{$X^{2}$} & \multirow[b]{2}{*}{$\mathbf{P}$} \\
\hline & & Baik & Cukup & Kurang & & & \\
\hline \multirow{2}{*}{ Usia $<40$ tahun } & $\sum$ & 83 & 11 & 1 & 95 & \multirow{6}{*}{0,192} & \multirow{6}{*}{0,908} \\
\hline & $\%$ & $87,4 \%$ & $11,6 \%$ & $1,1 \%$ & $100 \%$ & & \\
\hline \multirow{2}{*}{ Usia $\geq 40$ tahun } & $\Sigma$ & 13 & 2 & 0 & 15 & & \\
\hline & $\%$ & $86,7 \%$ & $13,3 \%$ & $0,0 \%$ & $100 \%$ & & \\
\hline \multirow{2}{*}{ Total } & $\Sigma$ & 96 & 13 & 1 & 110 & & \\
\hline & $\%$ & $87,3 \%$ & $11,8 \%$ & $0,9 \%$ & $100 \%$ & & \\
\hline
\end{tabular}

Tabel 5 Hasil uji kebebasan chi-square tingkat pengetahuan dokter umum dan pengalaman praktik

\begin{tabular}{|c|c|c|c|c|c|c|c|}
\hline & & \multicolumn{3}{|c|}{ Nilai } & \multirow[b]{2}{*}{ Total } & \multirow[b]{2}{*}{$X^{2}$} & \multirow[b]{2}{*}{$\mathbf{P}$} \\
\hline & & Baik & Cukup & Kurang & & & \\
\hline \multirow{2}{*}{ Pernah } & $\Sigma$ & 55 & 3 & 0 & 58 & \multirow{6}{*}{6,503} & \multirow{6}{*}{0,039} \\
\hline & $\%$ & $94,8 \%$ & $5,2 \%$ & $0,0 \%$ & $100 \%$ & & \\
\hline \multirow{2}{*}{ Tidak } & $\Sigma$ & 45 & 10 & 1 & 52 & & \\
\hline & $\%$ & $78,8 \%$ & $19,2 \%$ & $1,9 \%$ & $100 \%$ & & \\
\hline \multirow{2}{*}{ Total } & $\Sigma$ & 96 & 13 & 1 & 110 & & \\
\hline & $\%$ & $87,3 \%$ & $11,8 \%$ & $0,9 \%$ & $100 \%$ & & \\
\hline
\end{tabular}

pengetahuan dokter umum mengenai bukti media kekerasan seksual dibuktikan dari nilai $\mathrm{p}>0,05$, yaitu $\mathrm{p}=0,908$.

\section{Pengaruh pengalaman praktik terhadap tingkat pengetahuan dokter umum mengenai bukti medis kekerasan seksual}

Variabel pengalaman praktik dibagi menjadi 2 kategori yaitu pernah menangani kasus kekerasan seksual dan tidak pernah menangani kasus kekerasan seksual.

Dari tabel 5 dapat diketahui bahwa proporsi dokter umur yang tingkat pengetahuan baik lebih tinggi pada kategori dokter umum yang pernah menangani kasus yaitu 94,8\% dibandingkan dokter umum yang tidak pernah menangani kasus yaitu $78,8 \%$ dengan ratio proporsi yaitu 1,20 . Ada hubungan yang bermakna antara pengalaman praktik dan tingkat pengetahuan dokter umum mengenai bukti medis kekerasan seksual dibuktikan dengan nilai p sebesar 0,032 lebih kecil daripada 0,05.

\section{DISKUSI}

Secara umum, tingkat pengetahuan dokter umum mengenai bukti medis kekerasan seksual adalah baik. Dilihat pada hasil penelitian dengan prevalensi dokter umum yang tingkat pengetahuan baik sebesar $87,3 \%$. Melihat hal tersebut, dokter umum memiliki tingkat pengetahuan yang baik untuk melakukan pemeriksaan bukti medis kekerasan seksual. Dari hasil analisis data didapatkan bahwa pengalaman praktik memiliki hubungan dengan tingkat pengetahuan dokter umum mengenai bukti medis kekerasan seksual. Hasil ini sesuai dengan penelitian yang telah dilaksanakan oleh Noviyani dan Bandi 2009 yang menyatakan bahwa pengalaman akan berpengaruh positif terhadap 
pengetahuan. Menurut teori WHO yang dikutip Soekijo Notoatmodjo, pengetahuan dapat diperoleh dari pengalaman. ${ }^{6}$

Penelitian ini memberikan hasil tidak didapatkan pengaruh yang bermakna antara usia dan tingkat pengetahuan dokter umum mengenai bukti medis kekerasan seksual. Hal ini menunjukkan bahwa seorang dokter yang berada dalam kelompok usia tertentu belum tentu memiliki tingkat pengetahuan yang lebih baik daripada kelompok usia lain. Banyak faktor lain yang dapat mempengaruhi pengetahuan seseorang, antara lain kondisi individu seperti intelegensia, daya tangkap, daya ingat, motivasi, dan sebagainya ${ }^{7}$ yang tidak selalu sejalan dengan usia seseorang. Namun, faktor-faktor ini tidak turut diperhitungkan dalam penelitian ini.

Kelompok usia dewasa madya (40-60 tahun) belum tentu memiliki pengalaman praktik atau mendapatkan kasus kekerasan seksual yang lebih banyak daripada kelompok dewasa awal $(<40$ tahun), begitu pula sebaliknya. Kelompok usia dewasa madya juga belum tentu memiliki kondisi individu yang lebih baik daripada kelompok dewasa awal, begitu pula sebaliknya.

\section{SIMPULAN}

Penelitian ini menggambarkan bahwa tingkat pengetahuan dokter umum yang berpraktik di Rumah Sakit Umum Daerah di Provinsi Bali mengenai bukti medis kekerasan seksual termasuk dalam kategori baik. Hal ini dapat dilihat dari hasil penelitian yang menunjukkan $87,3 \%$ memiliki tingkat pengetahuan baik, 11,8 \% memiliki tingkat pengetahuan cukup, dan 0,9\% memiliki tingkat pengetahuan kurang.

Usia seorang dokter tidak mempengaruhi tingkat pengetahuan dokter umum yang berpraktik di Rumah Sakit Umum Daerah di Provinsi Bali mengenai bukti medis kekerasan seksual secara bermakna sedangkan pengalaman praktik seorang dokter mempengaruhi tingkat pengetahuan dokter umum yang berpraktik di Rumah Sakit Umum Daerah di Provinsi Bali mengenai bukti medis kekerasan seksual secara bermakna.

\section{DAFTAR PUSTAKA}

1. Ashimi A, Amole T, Ugwa E. "Reported sexual violence among women and children seen at the gynecological emergency unit of a rural tertiary health facility, northwest nigeria." Annals of Medical and Health Sciences Research. 2015; 26-29. doi: 10.4103/2141-9248.149780.

2. Catatan Tahunan tentang Kekerasan terhadap Perempuan. Kekerasan terhadap Perempuan Meluas: Negara Urgen Hadir Hentikan Kekerasan terhadap Perempuan di Ranah Domestik, Komunitas dan Negara. Komisi Nasional Anti Kekerasan Terhadap Perempuan; 2016. [Online] https:// www.komnasperempuan.go.id/file/pdf_file/Catatan $\% 20$ Tahunan/14.PP5_CATAHU\%202016.pdf [18 November 2017]

3. Komisi Perlindungan Anak Indonesia. Kasus Pengaduan Anak Berdasarkan Klaster Perlindungan Anak; 2016. [Online] file:///C:/Users/user/Downloads/DATA\%20 KPAI\%20UPDATE\%20PER\%2024\%20OKTOBER\%20 2016\%20(2).pdf [18 November 2017]

4. Erviantono T, Pascarani D, Mirayani E, Leita M. Laporan Penelitian Kerjasama Institute of Peace and Democracy dengan Program Studi Ilmu Administrasi Negara Fakultas Ilmu Sosial dan Ilmu Politik Universitas Udayana Making Women's Political Engagement Effective. Fakultas Ilmu Sosial dan Ilmu Politik Universitas Udayana; 2014.

5. Jackson, Cathryn. Cluster Random Samples: Definition, Selection \& Examples. Studi.com;2016. [Online] Tersedia di http//:study.com/academy/lesson/cluster-randomsamples-definition-selection-examples.html

6. Wawan, Dewi. 2010. Teori \& pengukuran pengetahuan, sikap, dan perilaku manusia. Yogyakarta: Nuha Medika.

7. Notoadmojo S. 2007. Promosi kesehatan \& ilmu prilaku. Jakarta: Rinaka Cipta.

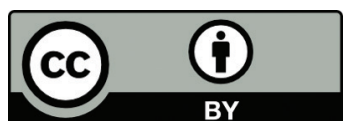

This work is licensed under a Creative Commons Attribution 